\title{
Prevalence of empathy, anxiety and depression, and their association with each other and with sex and intended specialty in medical students
}

\author{
Prevalência de empatia, ansiedade e depressão, e sua associação entre si e com gênero e especialidade almejada \\ em estudantes de medicina
}
Camila Brunfentrinker ${ }^{1}$ (D) cammy.tag@gmail.com Regina Pinho Gomig² (D) rginapinho@hotmail.com Suely Grosseman ${ }^{1,3}$ (D) sgrosseman@gmail.com

\begin{abstract}
Introduction: Empathy and mental health are crucial for medical students' self-care and performance as well as for patient care.

Objective: to assess the prevalence of empathy, anxiety and depression, and their association with each other and sex, intended specialty and course semester.

Method: Cross-sectional study with 405 of 543 students (74.6\%) from odd semesters and from the $12^{\text {th }}$ semester of the medical course of two universities in southern Brazil. Data were collected using a self-administered questionnaire containing information on age, sex, medical course semester, intended specialty, Jefferson Scale of Empathy (JSE) and Beck Anxiety and Depression Inventories (BAI and BDI). The data were analyzed using descriptive statistics, Student's t-tests, Chi-square, and bidirectional ANOVA between groups. The level of significance was set at $p<0.05$.

Results: The mean JSE score was $120.2(S D=10.6)$ [116.9 $(S D=11.0)$ in men and $123.4(S D=9.2)$ in women, $p=0.000]$, being higher among students who wanted to follow medical areas aimed at people [123.1 (SD =10.1)], than among those whose intended areas aimed at techniques and procedures [118.5 (SD = 11.2)], $\mathrm{p}=.003$. There was no difference between the course periods. The anxiety and depression mean rates were, respectively, 16.2 $(\mathrm{SD}=11.3)$ and $11.9(\mathrm{SD}=9.0)$ [13.1 (SD = 10.3) and $9.9(\mathrm{SD}=8.3)$ in men and $19.1(\mathrm{SD}=11.4)$, and $13.8(\mathrm{SD}=9.4)$ in women, $\mathrm{p}=.000 \mathrm{for}$ both]. The prevalence rate of moderate and high anxiety was $33.8 \%$ and, when including mild anxiety, it was $59 \%$. The prevalence rate of dysphoria (BDI $=16$ 20 ) and depression (BDI > 20) was $26.4 \%$, and $11.9 \%$ for suicidal ideation. An association was observed between severe anxiety and the JSE subscale 'Walking in patient's shoes', more related to empathic stress.
\end{abstract}

Conclusions: Empathy is high and stable throughout the medical course at the studied institutions and higher in women and students who want to follow people-oriented specialties. Anxiety and depression have higher prevalence rates in women. Severe anxiety is associated with the JSE subscale 'Walking in patient's shoes'.

Keywords: Medical Students; Empathy; Anxiety; Depression; Medical Education.

\section{RESUMO}

Introdução: A empatia e a saúde mental são fundamentais para o autocuidado e desempenho do estudante de medicina e seu cuidado dos pacientes.

Objetivo: Avaliar a prevalência e associação entre empatia, ansiedade e depressão, e com gênero, especialidade almejada e período do curso em estudantes de medicina.

Método: Estudo transversal com 405 de 543 estudantes (74,6\%) de semestres ímpares e do $12^{\circ}$ semestre do curso de medicina de duas universidades do Sul do Brasil. Os dados foram coletados com questionário autoaplicado contendo idade, sexo, semestre do curso, especialidade almejada, Escala Jefferson de Empatia (JSE) e Inventários de Ansiedade e de Depressão de Beck (BAl e BDI). Os dados foram analisados com estatística descritiva, testes $t$-Student, Chi-quadrado e ANOVA bidirecional entre grupos. O nível de significância admitido foi de $p<0,05$.

Resultados: A média da JSE foi de 120,2 (DP=10,6) [116,9 (DP=11,0) em homens e 123,4 (DP=9,2) em mulheres, $p=0,000]$ e maior entre estudantes que almejavam áreas médicas voltadas a pessoas $[123,1(D P=10,1)]$ do que entre os que almejavam áreas voltadas a técnicas e procedimentos $[(118,5(D P=$ $11,2)], p=0,003$. Não houve diferença por período do curso. As médias de ansiedade e depressão foram, respectivamente, de 16,2 (DP =11,3) e 11,9(DP=9,0) $[13,1(D P=10,3)$ e 9,9 $(D P=8,3)$ em homens, e 19,1 (DP=11,4) e 13,8 (DP=9,4) em mulheres, $p=0,000$ para ambas]. A prevalência de ansiedade moderada e alta foi de 33,8\%, e, incluindo-se ansiedade leve, de 59\%. A prevalência de disforia (BDI = 16-20) e depressão (BDI > 20) foi de 26,4\%, e de $11,9 \%$ para ideação suicida. A ansiedade grave associou-se à subescala Walking in patient's shoes da JSE, mais relacionada ao estresse empático.

Conclusões: A empatia é alta, estável ao longo do curso nas instituições estudadas e maior entre mulheres e estudantes que almejam especialidades voltadas a pessoas. A prevalência de ansiedade e depressão é alta e maior nas mulheres. A ansiedade grave se associou à subescala "colocar-se no lugar do paciente" da JSE.

Palavras-chave: Estudantes de medicina; Empatia; Ansiedade; Depressão; Educação Médica.

1 Universidade Federal de Santa Catarina, Florianópolis, Santa Catarina, Brazil.

${ }^{2}$ Universidade do Oeste de Santa Catarina, Joaçaba, Santa Catarina, Brazil.

${ }^{3}$ Faculdades Pequeno Príncipe, Curitiba, Paraná, Brazil.

Chief Editor: Rosiane Viana Zuza Diniz. $\quad$ | Associate Editor: Fernando Antonio de Almeida.

Received on 04/30/21; Accepted on 07/13/21. | Evaluated by double blind review process. 


\section{INTRODUCTION}

Medical students' empathy and mental health influence their self-care, academic performance, and patient care. However, several factors can affect them before and during academic training ${ }^{1,2}$.

When choosing Medicine as a profession, many students are still transitioning from adolescence to adulthood, with different adaptation demands that can worsen their mental health. The preparation for admission at the medical course usually requires great dedication to studies due to the extremely competitive selection process. After entering the course, it is necessary to adapt to several aspects, such as: socializing with new classmates and teachers; new teaching and learning methods; full-time course; usually frequent and overlapping evaluations that require continuous study of excessive new contents; activities that can undermine one's emotional capacity, such as anatomy classes with cadavers. For some, being away from one's family, having to live alone or with new roommates, and financial and/or access to food limitations are also added ${ }^{3}$. In addition to fatigue, stress and anxiety, time limitation due to the pressures of the course usually interferes with opportunities for leisure and interaction with family and friends. Throughout the course, the students deal with the suffering of patients and their loved ones, with death, and receive messages about professional values and attitudes from people with whom they live, which are often ambiguous and can make them vulnerable and confused about their deepest values.

In the final semesters of the course, there is also progressive responsibility for patient care, shifts, doubts about which specialty they intend to follow and stress regarding the tests for medical residency or for a job that will be the first source of income after six years of training, which limit economic independence ${ }^{1,2,4-9}$.

The diagnosis of anxiety and depression is associated with the duration, frequency and intensity of manifestations of mood and affective disorders ${ }^{10}$. Dyrbye et al., in a systematic review, found a higher prevalence of depression and anxiety in medical students from Canada and the United States than in the general population'. Other studies have also observed this same phenomenon ${ }^{11-19}$ and some have also found a higher risk of suicide among medical students ${ }^{12-19}$.

A meta-analysis on anxiety among medical students including 18 studies from Asia, 21 from the Middle East, 13 from Europe, 10 from South America, 4 from North America, two from Oceania and one from Africa, totaling 40,348 medical students, found an overall prevalence of $33.8 \%(95 \% \mathrm{Cl} 29.2$ $38.7 \%)$, higher than that in the general population ${ }^{18}$.

A recent analysis of 10 systematic reviews on depression among medical students, including 249 articles written in
English, Chinese, Spanish or Portuguese, totaling 162,450 medical students, showed a prevalence of $27.0 \%$ (95\%Cl: $24.7-$ 29.5\%). Eight studies were carried out in Africa, 49 in North or Central America, 37 in South America, 107 in Asia, 46 in Europe and 3 in the Western Pacific Region. The authors also found that the course semester, sex, personal problems and health conditions as the main factors associated with depressive symptoms ${ }^{19}$. Moreover, a meta-regression including 106 studies from 32 countries, totaling 84,119 participants, found that women had a greater chance of depression than men (Odds ratio $=1.3,95 \% \mathrm{Cl}: 1.17-1.44, \mathrm{p}<0.01)^{16}$. Another systematic review including 178 studies from 43 English-speaking countries also found a prevalence of suicidal ideation of $11.1 \%(95 \% \mathrm{Cl}=9.0$ $13.7 \%$ ) in 24 studies from 15 countries that mentioned it ${ }^{12}$.

Studies have shown a relationship between depressive disorders and changes in empathy. According to Rogers, empathy is the ability to enter the perceptual world of another person and try to understand their feelings and their perspective of the world, however, without losing sight of their own perspective ${ }^{20,21}$. It is a multidimensional construct, and there is no consensus regarding its dimensions ${ }^{22}$. Morse et al. consider that empathy includes the emotional dimension (intrinsic ability to understand feelings), the moral dimension (motivation to want to understand the other), the cognitive dimension (correctly understanding the perspectives and feelings of others - empathic accuracy) and the behavioral dimension (ability to communicate and understand such feelings) ${ }^{23}$. Hojat et al., however, consider more the cognitive dimension, which involves understanding the patients experiences and concerns and the ability to communicate this understanding to them ${ }^{24}$. Schreiter et al., based on several authors, including Davis, who built the Interpersonal Reactivity Index (IRI), consider that empathy includes the affective and cognitive dimensions. The affective dimension would comprise two components. One component is empathic concern, which leads a person to have "compassion" for and care about the other. Another component is empathic stress, characterized by recalling experienced situations and sharing the pain of seeing other people suffering. The cognitive dimension - cognitive empathy - would be the ability to understand another person's perspective, which results in greater empathic accuracy ${ }^{25}$.

People with subclinical depression also seem to have impaired social performance even after depression remission, which can influence the persistence or worsening of depression because they tend to avoid social interactions with those who could help them to overcome difficult times ${ }^{26,27}$. There is also the possibility that certain brain areas that are affected in depression may lead to difficulties in social communication and the ability to perceive and understand others, which is 
crucial for empathy ${ }^{28}$. A systematic review including 37 studies written in English analyzed the association between empathy in adults with a primary diagnosis of major or subclinical primary depression who had not sought help, and who had no other mental or somatic diseases. It was verified that people with depression had no alterations in empathic concern but tended to have greater emphatic stress and less cognitive empathy. The study by Schreiter et al. showed that depression rates, in addition to being higher among women, could result in a greater decrease in cognitive empathy for women than for men with depression; however, the authors call attention to limitations in the studies analyzed, as all of them were crosssectional, with variation in the population included in each study and in the instruments used to assess depression. Also, some used instruments were filled out by the participant, which made them more subject to bias ${ }^{25}$.

As empathy is a component of medical professionalism ${ }^{29-31}$ and one of the pillars of the doctor-patient relationship, it has been extensively investigated ${ }^{32-35}$. Studies show that more empathetic physicians, with more patientcentered communication skills establish better bonds with their patients and have better therapeutic results, such as shorter duration of the common cold ${ }^{36}$, better control of glycemia and diabetes 37,38 , reduced anxiety by their patients and increased strategies to face their health problems ${ }^{39,40}$. Taking into account their importance in the health area, Hojat et al. developed the Jefferson Scale of Empathy (JSE) to assess empathy in medical education and health care ${ }^{24}$. The JSE has good internal consistency and, by 2012, it had been translated and validated in over 40 countries. The scale contains 3 subscales (factors): Perspective taking, more related to the cognitive dimension of empathy; Compassionate care, more related to the affective dimension, regarding the sense of caring about the patient's feelings; and Walking in Patient's shoes, which means "putting oneself in the other's place", which could be considered as putting themselves in the patient's shoes, which can cause empathic stress ${ }^{41-43}$. A study conducted by Hojat et al. found a decrease in empathy in the $3^{\text {rd }}$ year of the medical course, when the clinical period or internship in American universities starts ${ }^{44}$. However, a meta-analysis with 12 studies on empathy in medical students throughout the course, restricted to articles written in English, with no date restriction, found a variation in its levels, especially in studies that used the JSE ${ }^{45}$. Another recent systematic review to assess empathy and the variables that influenced it, including 30 articles published between 2010 and 2019 in English and Scandinavian, 25 of which used the JSE, found a decline in empathy over the medical course in only 14 studies and its stability, or even an increase, in the other 16. This variation occurred not only between countries, but also between different institutions in the same country. Empathy was greater in women in 18 of 27 studies and among students with an intended specialty focused on people in three of nine studies ${ }^{46}$. According to Hojat, people-oriented specialties are those in which the doctor has frequent meetings with patients to monitor their health over a long period of time, which includes family doctors, clinicians, pediatricians, gynecologists/ obstetricians and psychiatrists. Technology or procedureoriented specialties encompass the other specialties, including clinical specialists (such as cardiologists or gastroenterologists) and anesthetists, surgeons, pathologists and radiologists ${ }^{43}$.

Therefore, given the importance of medical students' empathy and mental health, the following research questions were raised: How is empathy, anxiety and depression among medical students and how are they related? Is there a difference in these variables between students attending a private institution and another attending a public institution, with different curricula? What are the associations between empathy, anxiety, depression with age, sex and intended specialty by these students?

To answer these questions, the aim of this study was to assess the prevalence of empathy, anxiety and depression, their association with each other and with sex, intended specialty and course semester.

Our hypotheses were: 1 . There is no difference between students attending courses in private and public institutions; 2. The prevalence of anxiety is around 34\% and of depression is 27\% among the students; 3. Empathy, anxiety and depression are greater among women; 3. Empathy is greater among students who intend to pursue people-oriented specialties; 4. Anxiety and depression are negatively correlated with empathy.

\section{METHOD}

\section{Study design and ethical precepts}

This was a cross-sectional, descriptive study, authorized by the JSE author for its use in research, by the Psychology Association for the use of Beck's Depression and Anxiety Inventories, and by the two assessed institutions, Universidade do Oeste de Santa Catarina (UNOESC) and Universidade Federal de Santa Catarina (UFSC). The research project was approved by the Ethics Committee for Research on Human Beings at UFSC, with CAAE 66299217.3.0000.0121, under number 2.280.876. Data were collected only after all approvals. Before applying the research, the objectives, the method and all the ethical precepts of the research were explained to the participants, and two copies of the Free and Informed Consent Form or Informed Assent Form were then delivered for those under 18 years of age, one of which was left with the participant and another with the researcher. 


\section{Participants}

The participants were medical students from the $1^{\text {st }}, 3^{\text {rd }}$, $5^{\text {th }}, 7^{\text {th }}, 9^{\text {th }}, 11^{\text {th }}$ and $12^{\text {th }}$ semesters regularly enrolled in the course in the second semester of 2018 at UFSC and UNOESC. Students attending the first semester and $11^{\text {th }}$ and $12^{\text {th }}$ semesters were included to allow comparisons between the initial and final semesters of the course.

UFSC has an integrated modular curriculum and a federal administrative link, hereafter called University A. UNOESC has a problem-based curriculum and its administrative link is a private one, and henceforth will be called University B.

Inclusion criteria: students present in the classroom on the day of data collection who agreed to participate in the study.

Exclusion criteria: not filling out more than 4 questions on the Jefferson Scale of Empathy or filling them out using the same number, and not filling out Beck's Anxiety Inventory (BAI) and the Beck's Depression Inventory (BDI).

\section{Data collection}

Data collection was carried out using a self-administered questionnaire containing participant identification data (the 7 middle numbers of the ITIN - Individual Taxpayer Identification Number-, university of origin), course semester, sex, age, intended specialty, empathy assessed by JSE, version validated for Brazilian Portuguese for students ${ }^{38}$, BAI and BDI.

The JSE is a self-completed instrument comprising twenty items, answered on a seven-point scale, where 1 is equivalent to "strongly disagree" and 7 to "strongly agree". Its score is calculated by the sum of the values of each item after the inversion of 10 items, reaching a minimum value of 20 points and a maximum of 140 points, with the highest level of empathy being considered for the highest scores ${ }^{24,41-43}$. As the scale consists of 3 factors (subscales), the scores for each factor can also be calculated. These factors are: Perspective taking (items 2, 4, 5, 9, 10, 13, 15, 16, 17 and 20), Compassionate care (items $1,7,8,11,12,14,18$ and 19) and Walking in Patient's shoes (items 3 and 6$)^{43}$.

The BAl is a scale to measure the presence and severity of anxiety symptoms. It consists of 21 items, answered on a scale ranging from 0 to 3 , according to the presence and intensity of symptoms that affect the respondent. Its score is calculated by the sum of the values in each item. The cutoff points for the classification of anxiety described in the Brazilian inventory manual are: 0 to 10: minimal; 11 to 19: mild; 20 to 30: moderate; and 31 to 63 : severe ${ }^{47}$.

The BDI I aims to identify and assess the severity of symptoms of depression. It consists of 21 items with statements, from which the respondent selects the one(s) that best describe how they felt in the previous week. If the participant checks more than one option, the highest one is considered. The score is calculated by the sum of the scores on the items. The recommended cutoff points for the classification of the Brazilian version of the $\mathrm{BDI} \mathrm{I}^{47}$ are: 0 to 11 : minimal depression; 12 to 19 : mild depression; 20 to 35: moderate depression; from 36 to 63 : severe depression. Kendal et al. warn that the BDI should be used as a measure of depression syndrome, but that its scores alone are insufficient as an index of nosological depression, as they may reflect other diagnoses such as schizophrenia, anxiety disorders and substance abuse, and may be affected by aspects such as stressful life events. The authors suggest that other affective states be aggregated to depression research to identify which effects are specific to depression in relation to other mood conditions. They criticize its classification because, even when the total score is equal to zero, the respondent is classified as having minimal depression, instead of being identified as having no depression. They also claim that cutoff points for depression such as 10 or 16 can generate false positive diagnoses. They recommend that individuals with scores up to 9 and mild depression between 10 and 20 be considered without alterations but consider that people with scores up to 17 could be considered dysphoric (non-specific negative affectivity). Scores above 17 would increase the probability of having depression, which should be considered moderate when scores are between 20 and 30 , and severe when above $30^{48}$. The recommendation of a score limit above 20 for depression and below this cutoff point for dysphoria has been adopted in Brazil in studies with university ${ }^{49}$ and medical students ${ }^{50}$. Gorenstein et al. adopted the BDI cutoff points of less than 16 for normality, 16 to 20 for dysphoria, and more than 20 for depression in the non-clinical subgroup in their study to assess the psychometric properties of the Brazilian version of the $\mathrm{BDI}{ }^{49}$. Therefore, in this study, in addition to the classification recommended in the Brazilian version ${ }^{47}$, this classification will also be considered ${ }^{49}$.

\section{Data analysis}

The data were entered and analyzed using the software Statistical Package for Social Sciences (SPSS), Version 26.0 for Windows.

In addition to the individual analysis of the variable course semester, this was also grouped as the initial period $\left(1^{\text {st }}\right.$ and $3^{\text {rd }}$ semesters), intermediate ( $5^{\text {th }}$ and $7^{\text {th }}$ semesters) and end of the course $\left(9^{\text {th }}, 11^{\text {th }}\right.$ and $12^{\text {th }}$ semesters) for more robust analyses.

The statistical analysis was descriptive with absolute and relative frequencies for categorical data and mean and standard deviation for continuous variables. Student's $t$ test and chi-square test were used to verify associations in categorical variables between two groups, and One-Way Analysis of Variance (ANOVA) for more than two groups in 
continuous variables. Spearman's correlation test was used to study the correlation between continuous variables. Multiple regression analysis was used having as dependent variable the empathy by JSE and its JSE subscales, anxiety (BAI) and depression (BDI), and age, sex, course semester, grouped course semester and intended specialty as the independent variables. Two-Way Analysis of Variance was used to analyze the individual and joint effect of two independent variables with different groups on a dependent variable, of which effect size was calculated by $\mathrm{Eta}^{2}$, interpreted as small when $<0.01$, moderate when equal to 0.06 and large when equal to 0.14 , according to Cohen, as cited by Pallant ${ }^{51}$.

The accepted level of significance was set at $p<0.05$.

\section{RESULTS}

Of the 543 students attending the $1^{\text {st }}, 3^{\text {rd }}, 5^{\text {th }}, 7^{\text {th }}, 9^{\text {th }}$, $11^{\text {th }}$ and $12^{\text {th }}$ semesters at Universities A and B, 414 (76.2\%) answered the questionnaire; nine were excluded, four for giving the same scores in the JSE and five for not completing all the items on the scales, totaling 405 students (74.6\%) for the analysis. Four participants did not provide information about their sex. Of the 231 students from university $A, 127$ were males and 104 females, while of the 170 students from university $B$, 67 were males and 103 females, $X^{2}(1)=9.5, p=0.002$.

The mean age of the participants was 22.9 years (Standard Deviation - SD = 3.4), with no difference between females (22.9 years, $\mathrm{SD}=3.2)$ and males $(22.9$ years, $\mathrm{SD}=3.6), \mathrm{t}(399)=0.104$,

Table 1. Mean values of empathy, anxiety and depression in 405 medical students per university and course semester.

\begin{tabular}{|c|c|c|c|c|c|}
\hline \multirow{2}{*}{ University } & \multirow{2}{*}{ Semester } & \multirow{2}{*}{$n$} & Empathy (JSE) ${ }^{\mathrm{a}}$ & Anxiety $(\mathrm{BAI})^{\mathrm{b}}$ & Depression (BDI) \\
\hline & & & Mean (SD) & Mean (SD) & Mean (SD) \\
\hline \multirow[t]{5}{*}{$A$} & $1^{\text {st }}$ & 43 & $116.2(12.0)$ & $19.0(11.8)$ & $11.1(8.8)$ \\
\hline & $5^{\text {th }}$ & 37 & $118.9(10.1)$ & $14.5(7.8)$ & $12.0(7.8)$ \\
\hline & $7^{\text {th }}$ & 33 & $122.2(8.5)$ & $13.6(10.1)$ & $12.0(9.0))$ \\
\hline & $12^{\text {th }}$ & 34 & $121.2(10.9)$ & $14.7(12.8)$ & $9.8(7.7)$ \\
\hline & Total & 234 & $119.2(10.5)$ & $15.4(11.0)$ & $11.8(8.7)$ \\
\hline \multirow[t]{5}{*}{ B } & $1^{\text {st }}$ & 24 & $122.2(10.8)$ & $15.4(13.7)$ & $11.7(13.2)$ \\
\hline & $3^{\text {rd }}$ & 28 & $125.0(10.2)$ & $17.3(11.8)$ & $11.6(6.7)$ \\
\hline & $11^{\text {th }}$ & 18 & $119.1(9.5)$ & $28.8(11.7)$ & $23.1(13.2)$ \\
\hline & $12^{\text {th }}$ & 16 & $115.1(14.8)$ & $14.5(7.3)$ & $8.4(7.4)$ \\
\hline & Total & 171 & $121.6(10.7)$ & $17.3(11.6)$ & $12.1(9.5)$ \\
\hline \multirow[t]{6}{*}{ Total $^{\mathrm{a}}$} & $1^{\text {st }}$ & 67 & $118.4(11.9)$ & $17.7(12.5)$ & $11.3(10.5)$ \\
\hline & $3^{\text {rd }}$ & 70 & $121.3(10.5)$ & $17.9(12.8)$ & $13.7(9.0)$ \\
\hline & $5^{\text {th }}$ & 71 & $121.9(9.8)$ & $13.6(7.7)$ & $10.9(6.8)$ \\
\hline & $7^{\text {th }}$ & 61 & $121.9(9.3)$ & $15.8(10.7)$ & $11.7(7.8)$ \\
\hline & $9^{\text {th }}$ & 57 & $119.1(10.1)$ & $14.6(9.7)$ & $11.0(8.0)$ \\
\hline & $11^{\text {th }}$ & 29 & $118.2(9.7)$ & $21.9(13.6)$ & $18.1(13.7)$ \\
\hline
\end{tabular}

Abbreviations - n: number of students; JSE: Jefferson Scale of Empathy; SD: Standard deviation; BAI: Beck Anxiety Inventory; BDI: Beck Depression Inventory.

a. Two-way between groups Analysis of Variance - University: $F(1)=2.77, p=0.097$; semester course: $F(6)=1.63, p=0.138$; University*Semester Interaction: $F(6)=2.72, p=0.013$, partial Eta $=0.040$ [University B: mean in the $12^{\text {th }}$ semester was lower than means in the $3^{\text {rd }}(p=0.041)$ and $5^{\text {th }}$ $(p=0.029)$ semesters .

b. Two-way between groups Analysis of Variance - University: $F(1)=7.03, p=0.008$, partial Eta ${ }^{2}=0.018$, Semester: $F(6)=1.77, p=0.104$, University*Semester Interaction: $F(6)=4.29, p=0.000$, partial Eta ${ }^{2}=0.062$ (University B with a higher mean in the $11^{\text {th }}$ semester than in all other semesters).

c. Two-way between groups Analysis of Variance - University: $F(1)-1.17, p=0.28$, Semester: $F(6)=3.39, p=0.02$, partial Eta ${ }^{2}=0.037($ University $B$ : higher mean in the $11^{\text {th }}$ semester than in the $12^{\text {th }}$ semester), University* Semester Interaction: $F(6)=3.39, p=0.003$, partial Eta ${ }^{2}=0.049$.

Source: the authors. 
$p=0.92$ and no difference between the universities (University A: females $=23.2, \mathrm{SD}=3.4, \mathrm{n}=104$ and males $=23.1, \mathrm{SD}=4.0, \mathrm{n}$ = 127; University $\mathrm{B}$ : females $=22.6, \mathrm{SD}=2.8, \mathrm{n}=1-3$ and males $=22.7, \mathrm{SD}=2.8, \mathrm{n}=67, \mathrm{t}(229)=-0.194, \mathrm{p}=0.846)$.

Table 1 shows the mean values of empathy, anxiety and depression per university and per attended course semester. As observed, at university $B$, the mean value of empathy was lower in the $12^{\text {th }}$ semester than in the $3^{\text {rd }}$ and $5^{\text {th }}$ semesters, while anxiety was higher in the $11^{\text {th }}$ semester than in all other semesters and depression was higher in the $11^{\text {th }}$ than when compared to the $12^{\text {th }}$ semester.

Figure 1 shows the overall mean of empathy, analyzed with the JSE, by sex, course period and intended specialty, assessed with the JSE. It is observed that the mean was high

Figure 1. Empathy (Jefferson Scale of Empathy) among 401 medical students by sexa, course period, intended specialty and their interactions ${ }^{b, c}$.

\section{Jefferson Scale of Empathy}

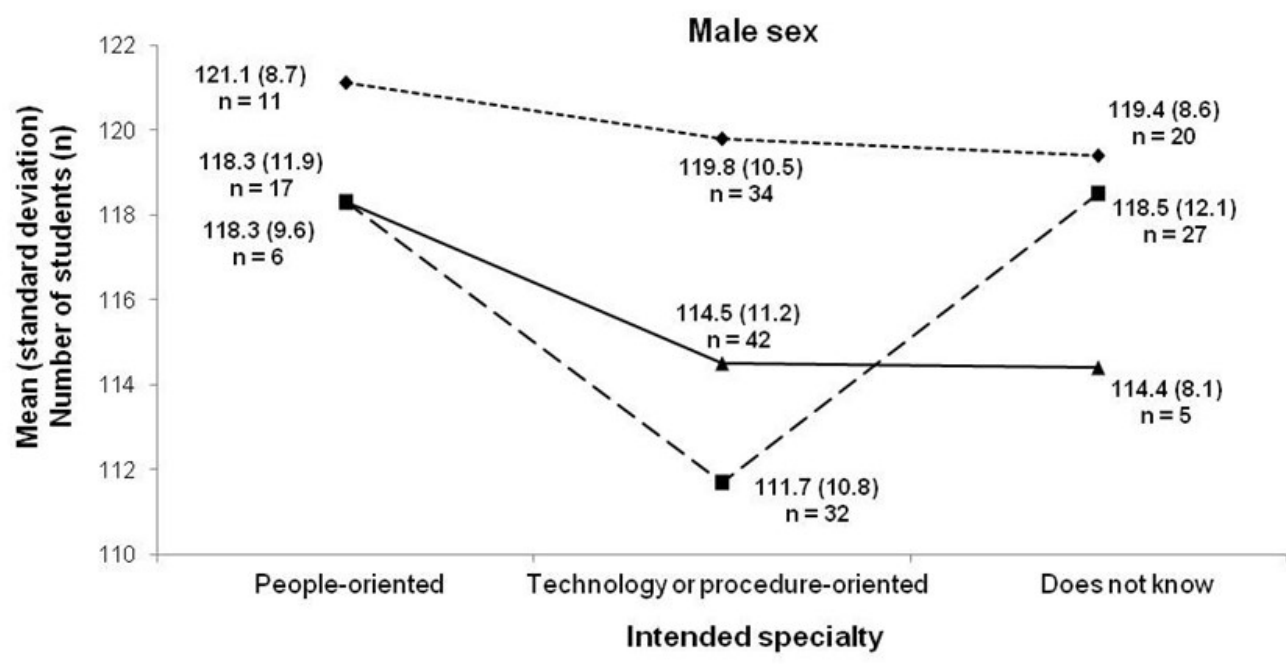

Course period

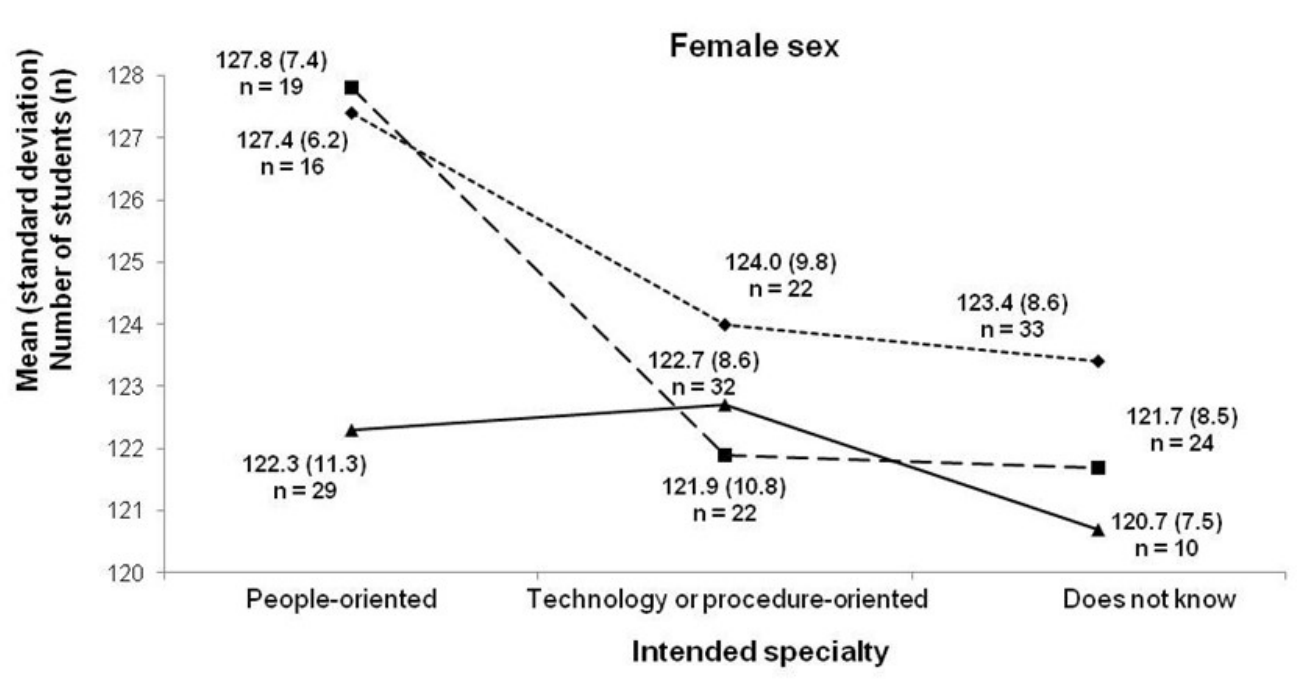

a. Four students did not fill out the sex variable.

b. The mean score in the Jefferson Scale of Empathy (JSE) among the 405 participants was 120.2 (SD = 10.6) [116.9, SD = 11.0 for males, and 123.4 $(S D=9.2)$ for females, $\mathrm{t}(377.1)=-6.5, \mathrm{p}=0.000]$; the mean score in the JSE in the initial period of the course was $120.0(\mathrm{SD}=11.2)[115.1(\mathrm{SD}=$ 11.6) in males and 124.5 (SD = 8.6) in females, $(117.2)=-5.29, \mathrm{p}=0.000], 121.7(\mathrm{SD}=9.6)$ in the intermediate period $[119.9, \mathrm{SD}=9.5$ in males and $123.6, \mathrm{SD}=9.3$ in females, $\mathrm{t}(128)=-2.21, \mathrm{p}=0.029]$ and $110.0, \mathrm{SD}=10.8$ at the end of the course $(115.5, \mathrm{SD}=11.1$ in $\mathrm{males}$ and $122.3, \mathrm{SD}=9.5$ in female, $\mathrm{t}(133)=-3.81, \mathrm{p}=0.000)$; the mean JSE score in students whose intended to pursue people-oriented specialties was 122.9 (SD $=10.2)$ [119.2 (SD = 10.4) in males and 125.2 (SD =9.4) in females, $\mathrm{t}(96)=-2.89, \mathrm{p}=0.005]$, in those whose intended to follow technology or procedureoriented specialties, it was $118.5(S D=11.2)[115.3(S D=11.2)$ in males and $122.9(S D=9.5)$ in females, $t(175.8)=-4.91, p=0.000]$ and among those who did not know the specialty they intended to pursue, it was 120.7 ( SD = 9.5) $[118.4(S D=10.4)$ in males and $122.4(S D=8.4)$ in females, $\mathrm{t}(117)=2.28, \mathrm{p}=0.024]$

c Two-way between groups Analysis of Variance - Sex: $F(1)=28.04, p=0.000$, partial Eta ${ }^{2}=0.068 ;$ Course period: $F(2)=2.38$, $p=0.09 ;$ Intended specialty: $F(2)=3.21, p=0.041$, partial $\mathrm{Eta}^{2}=0.016$ (difference between people-oriented specialties and other options, $\mathrm{p}=0.001$ ); Interactions: Sex ${ }^{*}$ Intended Specialty: $F(2)=0.64, p=0.53$; Sex ${ }^{*}$ Course semester: $F(2)=1.70, p=0.184$; Intended specialty* Course semester: $F(4)=0.70, p=0.059$; Sex ${ }^{*}$ Intended specialty*Course semester: $F(4)=0.91, p=0.46$.

Source: the authors. 
(shown in the observations), higher in the female sex and among students who intended to follow people-oriented specialties, regardless of the sex. There was no difference between the course semesters.

Figure 2 shows the mean scores of anxiety, analyzed with the BAl, by sex, course semester and intended specialty among the study participants. As observed, the female sex shows higher means.
Figure 3 shows the mean scores of depression, analyzed with the BDI, by sex, course semester and intended specialty. As observed, females have higher means of depression.

Table 2 shows the prevalence of anxiety and depression by sex and by university. As it can be observed, the prevalence of anxiety and depression was similar at both universities and higher among females.

Figure 2. Anxiety (Beck Anxiety Inventory) among 401 medical students by sexa , course semester and intended specialty and their interactions ${ }^{\mathrm{b}, \mathrm{c}}$.

\section{Beck Anxiety Inventory}
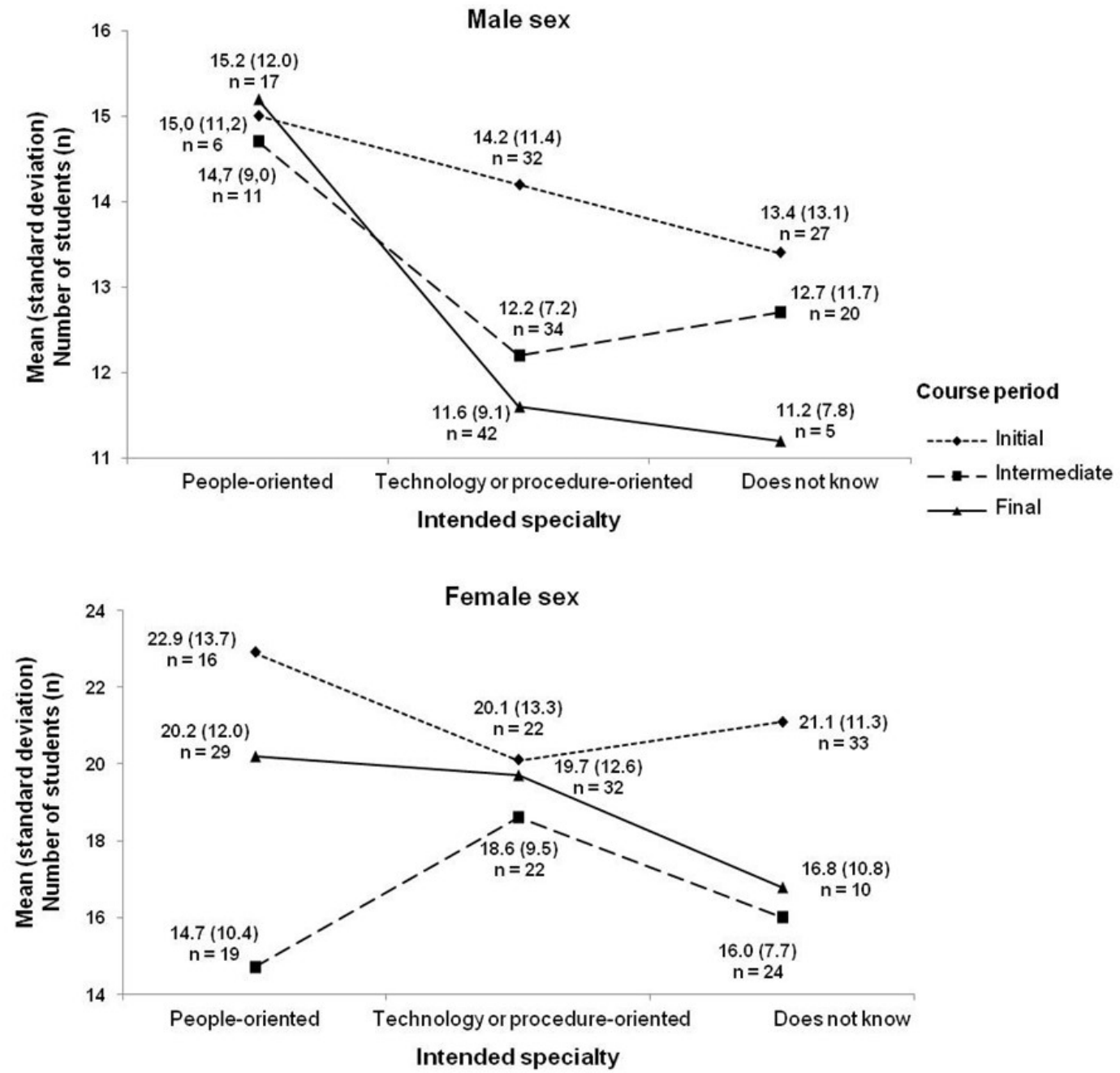

Abbreviations - n: number; numbers that appear followed by parentheses represent the mean and standard deviation.

a. Four students did not fill out the sex variable.

b. The average in the Beck Anxiety Inventory (BAl) was equal to $16.2(S D=11.3)$ [(13.1 $(S D=10.3)$ in males and $19.1(S D=11.4)$ in females, $t(398.5$ $=-5.5, p=0.000)]$; the BAI mean was $17.8(S D=12.6)$ in the initial period of the course $[14.0(S D=12,0)$ in males and $21.2(S D=12.3)$ in females, $\mathrm{t}(134)=-3.46, \mathrm{p}=0.001]$, whereas it was $14.6(\mathrm{SD}=9.2)$ in the intermediate $[12.8(\mathrm{SD}=9.0)$ in males and $16.5(\mathrm{SD}=9.1)$ in females, $\mathrm{t}(128)=-2.34$ $\mathrm{p}=0.021]$, and $16.2(\mathrm{SD}=11.5)$ at the end $[12.5(\mathrm{SD}=9.9)$ in males and $19.5(\mathrm{SD}=12.0)$ in females, $t(131.9)=-3.70, \mathrm{p}=0.000]]$. The $\mathrm{BAI}$ mean was $17.8(S D=11.8)$ among students who intended to pursue people-oriented specialties [15.0 $(S D=10.6)$ in males and $19.3(S D=12.2)$ in females, $t(96)=-1.71, p=0.089], 15.4(S D=11.0)$ among those who aimed at technology or procedure-oriented specialties, [12.6 (SD = 9.3) in males and $19.5(\mathrm{SD}=11.9)$ in females, $\mathrm{t}(136.1)=-4.25, \mathrm{p}=0.000$ ) and $16.1(\mathrm{SD}=11.3)$, among those who did not yet know the specialty they would choose $[13.0(S D=12.0)$ in males and $18.6(S D=10.2)$ in females, $t(117)=2.78, p=0.006]$.

c. Two-way between groups Analysis of Variance - Sex: $F(1)=18.30, p=0.000$, partial Eta ${ }^{2}=0.046$; Intended specialty: $F(2)=0.594, p=0.552$ (difference between people-oriented and the two other options, $\mathrm{p}=0.001$ ); Course semester: $\mathrm{F}(2)=2.0, \mathrm{p}=0.55$; Interactions - Sex Intended specialty: $F(2)=0.362, p=0.696$; Sex ${ }^{*}$ Course semester: $F(2)=0.939, p=0.392$; Targeted specialty* Course semester: $F(4)=0.257, p=0.905$; Sex Intended specialty ${ }^{*}$ Course semester: $F(4)=0.347, p=0.846$.

Source: the authors. 
Figure 3. Depression (Beck Depression Inventory) among 401 medical students by sex ${ }^{\text {, }}$, course semester, and intended specialty and their interactions ${ }^{\mathrm{b}, \mathrm{c}}$.

\section{Beck Depression Inventory}

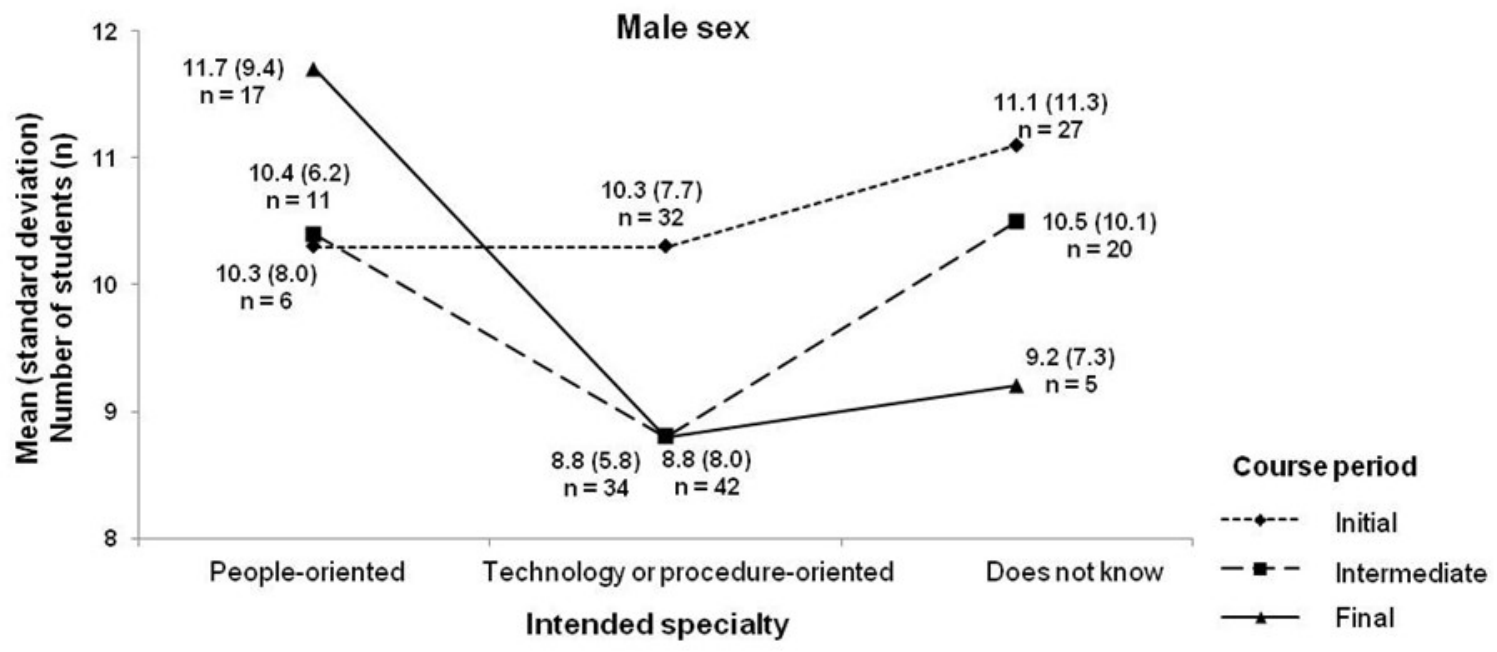

Female sex

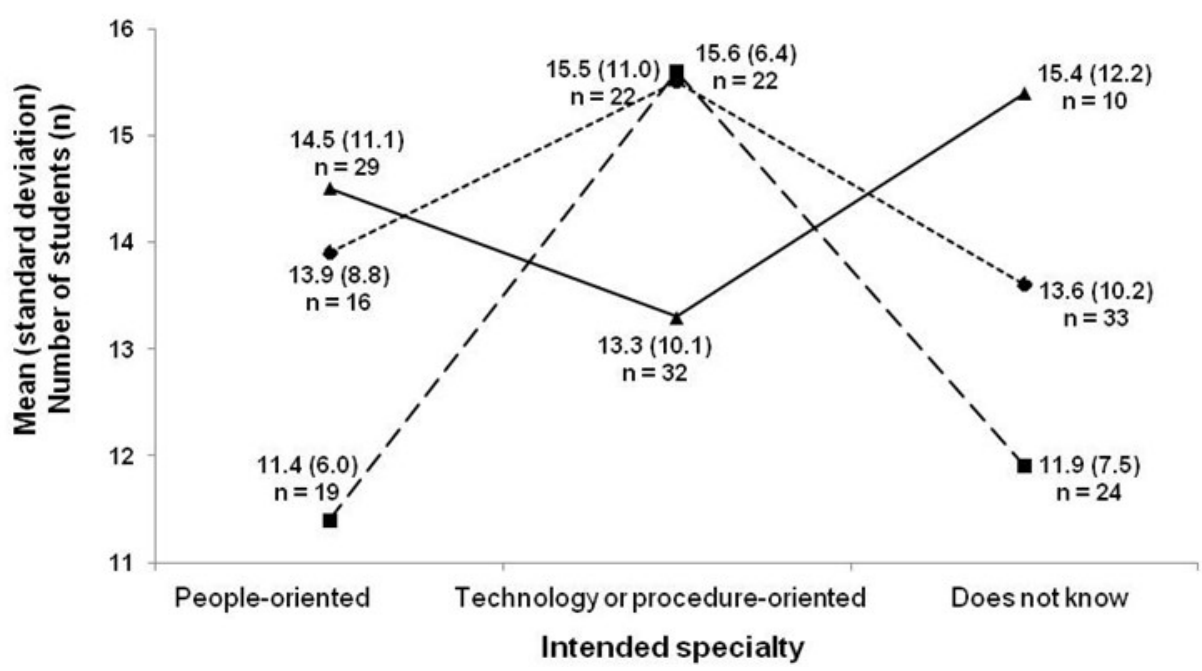

Abbreviations - n: number; numbers that appear followed by parentheses represent the mean and standard deviation.

a. Four students did not fill out the sex variable.

B. The mean score in the Beck Depression Inventory (BDI) was $11.9(\mathrm{SD}=9.0)[9.9(\mathrm{SD}=8.3)$ in males and $13.8(\mathrm{SD}=9.4)$ in females, $\mathrm{t}(397.8)=-4.39$, $\mathrm{p}=0.000]$. The mean score in the BDI in the initial period of the course was $12.6(\mathrm{SD}=9.8)[10.7(\mathrm{SD}=9.2)$ in males and $14.3(\mathrm{SD}=10.0)$ in females, $\mathrm{t}(134)=-2.19, \mathrm{p}=0.03]$, whereas in the intermediate period, it was $11.3(\mathrm{SD}=7.3)[9.6(\mathrm{SD}=7.4)$ in males and $13.0(\mathrm{SD}=6.9)$ in females, $\mathrm{t}(128)=$ $-2.7, p=0.008$ ] and at the end of the course was $12.0(S D=9.9),[9.6(S D=8.3)$ in males and 9.6 $(S D=8.3)$ in females, $t(130.2)=-274, p=0.006]$. The mean $\mathrm{BDI}$ score among those who intended to pursue people-oriented specialties was $12.6(\mathrm{SD}=8.9)[11.1(\mathrm{SD}=8.0)$ in males and $13.4(\mathrm{SD}=9.2)$ in females, $\mathrm{t}(96)=-1.28,=0.204]$, whereas it was $11.5(\mathrm{SD}=8.6)$ among those who aimed at technology or procedure-oriented specialties [9.2 (SD $=7.2)$ in males and $14.6(S D=9.4)$ in females, $t(134.0)=-4.39, p=0.000]$ and $12.1(S D=10.0)$ among those who did not know the specialty they would choose [10.7 (10.4) in males and $13.3(S D=9.6)$ in females, $t(117)=-141, p=0.16]$.

c. Two-way between groups Analysis of Variance - Sex: $F(1)=12.73, p=0.000$, partial Eta ${ }^{2}=0.032$; Targeted specialty: $F(2)=0.005, p=0.995 ;$ Course semester: $F(2)=0.370, p=0.691$; Interactions - Sex Intended Specialty: $F(2)=0.920, p=0.399$; Sex ${ }^{*}$ Course semester: $F(2)=0.166, p=0.847$; Intended specialty* Course semester: $F(4)=0.491, p=0.742$; Sex Intended specialty*Course semester: $F(4)=0.374, p=0.827$.

Source: the authors. 
Table 2. Prevalence of anxiety and depression by university and sex among medical students from two universities in southern Brazil.

\begin{tabular}{|c|c|c|c|c|c|c|c|c|}
\hline \multirow[b]{2}{*}{ Disorders } & \multicolumn{2}{|c|}{ Sex ${ }^{a}$} & \multirow{2}{*}{$\begin{array}{c}X^{2}(d f) \\
p(E t a, \text { if } \\
p<0.05)\end{array}$} & \multirow{2}{*}{$\begin{array}{l}\text { Sex } \\
\text { Total } \\
\text { n (\%) }\end{array}$} & \multicolumn{2}{|c|}{ University (U) } & \multirow{2}{*}{$\begin{array}{c}X^{2}(d f) \\
p(E t a, \text { if } \\
p<0.05)\end{array}$} & \multirow{2}{*}{$\begin{array}{c}\mathrm{U} \\
\text { Total } \\
\mathrm{n}(\%)\end{array}$} \\
\hline & $\begin{array}{c}\text { Male } \\
\text { n (\% in the } \\
\text { sex) }\end{array}$ & $\begin{array}{c}\text { Female } \\
\mathrm{n}(\% \text { in the } \\
\text { sex) }\end{array}$ & & & $\stackrel{\mathrm{A}}{\mathrm{n}(\% \text { at U) }}$ & $\begin{array}{c}\text { B } \\
\text { n (\% at } \\
\text { U) }\end{array}$ & & \\
\hline \multicolumn{9}{|l|}{ Anxiety $^{b}$} \\
\hline Minimal $(\mathrm{BAI} \leq 10)$ & $104(53.6)$ & $61(29.5)$ & \multirow{4}{*}{$\begin{array}{c}\mathrm{X}^{2}(3)=32,9 \\
p=0,000 \\
(0,29)\end{array}$} & $165(41.1)$ & $99(42.3)$ & $67(39.2)$ & \multirow{4}{*}{$\begin{array}{l}X^{2}(3)=3,7 \\
p=0,294\end{array}$} & $166(41.0)$ \\
\hline Mild (BAl:11 to 19$)$ & $48(24.7)$ & $52(25.1)$ & & $100(24.9)$ & $61(26.1)$ & $41(24.0)$ & & $102(25.2)$ \\
\hline Moderate (BAI: 20 to 30 ) & $32(16.5)$ & $59(28.5)$ & & $91(22.7)$ & $54(23.1)$ & $38(22.2)$ & & $92(22.7)$ \\
\hline Severe (BAI: $\geq 31$ ) & $10(5.2)$ & $35(16.9)$ & & 45 (11.2) & $20(8.5)$ & $25(14.6)$ & & $45(11.1)$ \\
\hline \multicolumn{9}{|l|}{ Depression $^{b}$} \\
\hline Minimal (BDI: 0 a 11) & $130(67.0)$ & $100(48.3)$ & \multirow{4}{*}{$\begin{array}{c}X^{2}(3)=19.4 \\
p=0.000 \\
(0.21)\end{array}$} & $230(57.4)$ & $134(57.3)$ & 99 (57.9) & \multirow{4}{*}{$\begin{array}{l}X^{2}(3)=0.8 \\
p=0.844\end{array}$} & $233(57.5)$ \\
\hline Mild (BDI:12 to 19) & $46(23.7)$ & $58(28.0)$ & & $104(25.9)$ & $61(26.1)$ & $44(25.7)$ & & $105(25.9)$ \\
\hline Moderate (BDI: 20 to 35) & $15(7.7)$ & $43(20.8)$ & & $58(14.5)$ & $35(15.0)$ & $23(13.5)$ & & $58(14.3)$ \\
\hline Severe (BDI: >35) & $3(1.5)$ & $6(2.9)$ & & $9(2.2)$ & $4(1.7)$ & $5(2.9)$ & & $9(2.2)$ \\
\hline \multicolumn{9}{|c|}{ Depression and dysphoriac } \\
\hline $\begin{array}{l}\text { Normal to minimal (BDI } \\
\text { up to } 15)\end{array}$ & 157 (80.9) & 137 (66.2) & \multirow{3}{*}{$\begin{array}{c}X^{2}(2)=14.1 \\
p=0.001 \\
(0.19)\end{array}$} & $294(73.3)$ & $171(73.1)$ & $\begin{array}{c}127 \\
(74.3)\end{array}$ & \multirow{3}{*}{$\begin{array}{c}X^{2}(2)=0.1 \\
p=0.94\end{array}$} & $298(73.6)$ \\
\hline $\begin{array}{l}\text { Dysphoria (BDI } \\
\text { between } 16 \text { and 20) }\end{array}$ & $20(10.3)$ & $25(12.1)$ & & $45(11.2)$ & $27(11.5)$ & $18(10.5)$ & & $45(11.1)$ \\
\hline Depression (BDI > 20) & $17(8.8)$ & $45(21.7)$ & & $62(15.5)$ & $36(15.4)$ & $26(15.2)$ & & $62(15.3)$ \\
\hline \multicolumn{9}{|l|}{ Suicidal Ideation } \\
\hline Yes & $19(9.8)$ & $29(14.0)$ & \multirow{2}{*}{$\begin{array}{l}X^{2}(1)=1.7 \\
p=0.194\end{array}$} & $48(12.0)$ & $26(11.1)$ & $22(12.9)$ & \multirow{2}{*}{$\begin{array}{c}X^{2}(1)=0.3 \\
p=0.59\end{array}$} & $48(11.9)$ \\
\hline No & $175(90.2)$ & $178(86.0)$ & & $353(88.0)$ & $208(88.9)$ & $\begin{array}{c}149 \\
(87.1)\end{array}$ & & $357(88.1)$ \\
\hline Total & $194(100.0)$ & $207(100.0)$ & $\begin{array}{c}X^{2}(3)=32.9 \\
p=0.000 \\
(0.29)\end{array}$ & $401^{\mathrm{a}}(100.0)$ & $234(100)$ & $\begin{array}{c}171 \\
(100)\end{array}$ & $\begin{array}{l}X^{2}(3)=3.7 \\
p=0.294\end{array}$ & $405(100.0)$ \\
\hline
\end{tabular}

Abbreviations - X2: Chi-square; df: degrees of freedom; U: University; BAl: Beck Anxiety Inventory; BDI: Beck Depression Inventory.

a Four participants did not fill out this variable, resulting in 401 students in this variable.

$\mathrm{b}$ Classification according to the Manual of the Portuguese version of the Beck Scales ${ }^{47}$.

c. Classification of the Brazilian version of the BDI used by Gorenstein et al..$^{49}$ for non-clinical subgroups.

Source: the authors.

Three students had had suicidal ideations in the week the questionnaire was applied, two from University $A$ and one from University $B$, one male and two females.

Student age was not associated with anxiety (according to Cunha's classification of anxiety), $F(3)=0.63, p=0.59$, nor with depression (according to Cunha's classification), $F(3)=1.78, p=$ 0.15 . There was also no association of age with minimal or mild depression (BDI < 16), dysphoria (BDI between 16 and 20) and presence of depression $(>20), F(2)=0.295, p=0.745$.

The overall JSE mean was not associated with anxiety (according to Cunha's classification of anxiety), $F(3)=0.80, p=$ 0.493 , or with depression (according to Cunha's classification), $F(3)=0.99, p=0.398$. There was also no association of empathy with minimal or mild depression (BDI < 16), dysphoria (between 16 and 20) and presence of depression (>20), F(2) = $0.93, p=0.396$.
There was an association between anxiety (according to Cunha's classification) and the JSE subscale 'Walking in Patient's shoes', $F(3)=6.2, p=0.00$. The mean of this subscale among students with minimal anxiety $(B A I \leq 10)$ in this subscale was $8.4(\mathrm{SD}=2.7), 7.9(\mathrm{SD}=2.7)$ among those with mild anxiety (BAI between 11 and 19), of $7.4(S D=2.6)$ among those with moderate anxiety (BAI between 20 and 30) and 9.5 ( $S D=3.1)$ among those with severe anxiety (BAI $\geq 31$ ). In the post-hoc test, statistically significant differences were identified, with the mean being higher among students with minimal anxiety compared to those with moderate anxiety, and also higher among students with severe anxiety compared to those with mild anxiety, with $p<0.05$. There was no association of anxiety with the 'Perspective taking' subscale, $F(3)=1.21, p=0.31$, or with the 'Compassionate care' subscale, $F(3)=1.70, p=0.917$. 
Depression (according to Cunha's classification) was not associated with the JSE 'Perspective taking', 'Compassionate care' and 'Walking in Patient's shoes' subscales, with ANOVA in each of these subscales of, respectively, $F(3)=1.0, p=0.40$, $F(3)=0.9, p=0.43$ and $F(3)=1.7, p=0.92$. There was also no association between minimal or mild depression (BDI < 16), dysphoria (BDI = 16 to 20) and presence of depression $(B D I>20)$ and these subscales, with ANOVA of, respectively, $F(2)=0.6, p=0.537, F(2)=0.94, p=0.39$ and $F(2)=0.51, p=$ 0.94). In students without suicidal ideation $(n=357)$ and those with suicidal ideation ( $n=48$ ), the mean of the 'Perspective taking' subscale was, respectively, $61.9(\mathrm{SD}=6.5)$ and 62.5 $(\mathrm{SD}=5.6), \mathrm{t}(403)=-0.6, \mathrm{p}=0.546$, whereas the mean of the 'Compassionate care' subscale was, respectively, 49.9 (SD = 5.2 ) and $50.8(\mathrm{SD}=3.6), \mathrm{t}(403)=-1.06, \mathrm{p}=0.29$, whereas that of 'Walking in Patient's shoes' was, respectively, 8.1 ( $S D=2.8$ ) and $8.9(\mathrm{SD}=2.9), \mathrm{t}(403)=-1.9, \mathrm{p}=0.054$.

\section{DISCUSSION}

In our study, the mean empathy score was high at both universities and higher among women. These findings are in line with articles included in the review by Andersen et al. ${ }^{46}$. As for the higher empathy among students who intended to follow people-oriented specialties, these authors also indicated studies with similar findings ${ }^{46}$.

Our initial hypothesis of a decline in empathy throughout the course was not confirmed, with no difference in empathy throughout the course in the two assessed universities, which is also in line with some studies from the meta-analysis by Spatoula et al., which found studies with variable findings ${ }^{45}$.

We also found that women showed higher mean values for depression and anxiety than men, which is in line with the findings of several studies ${ }^{12-14,16}$.

In our study, the prevalence of anxiety was 59\% when considering the presence of mild to severe anxiety (BAI $>10$ ). This prevalence is higher than the overall prevalence of anxiety in the meta-analysis by Tian-Ci Quek et al., which was $33.8 \%(95 \% \mathrm{Cl} 29.2$ - 38.7) and also higher than that found by these authors in Middle Eastern countries, which was 42.4\%, (95\% Cl: 33.3 - 52.1\%) and in Asian countries, which was $35.2 \%(95 \% \mathrm{Cl}: 26.3-45.3 \%)^{18}$. However, when considering only moderate to severe anxiety (BAI > 19), the prevalence of anxiety in our study was $33.8 \%$, equal to the overall prevalence found by these authors ${ }^{18}$. We therefore hypothesize that the higher prevalence found in our study is caused by the inclusion of mild anxiety.

As for depression, its prevalence did not differ between the two universities, being $42.4 \%$, if mild to severe depression is included $(\mathrm{BDI} \geq 12)$. This prevalence is well above the overall rate found in the review of systematic reviews by Tam and Pacheco, which was $27.0 \%$ (95\% Cl: $24.7-29.5 \%)$, and similar to those found by these authors in African countries, which was $40.9 \%$ (95\%Cl: $28.8-54.4 \%)^{19}$. However, when considering only values $>15$, which include dysphoria (BDI = 16 to 20$)$ and depression $(B D I>20)^{49}$, the prevalence of depression in our study is $26.4 \%$, similar to the overall rate found by Tam and Pacheco ${ }^{19}$.

The prevalence of suicidal ideation in our study was $11.9 \%$. This finding is of great concern, considering that approximately 12 of every 100 students had thought of suicide in the week preceding data collection. Similar findings were found by Rotenstein et al., which was $11.1 \%(95 \% \mathrm{Cl}=$ $9.0-13.7 \%)^{12}$.

Our initial hypothesis that anxiety and depression would increase throughout the course was not confirmed, with an increase being found only in the $11^{\text {th }}$ semester of the course in one of the universities.

An association was found between anxiety and the JSE 'Walking in Patient's shoes' subscale, which is equivalent to empathic stress, with a higher mean observed in students with severe anxiety. However, we did not find an association between this subscale and depression, as indicated in the literature, but we found its association with anxiety ${ }^{25}$. Moreover, there is a trend $(p=0.05)$ towards the association between suicidal ideation and this component, which should be further explored in future studies with a larger number of participants.

We did not find any association of JSE and its'Perspective taking' and 'Compassionate care' subscales with anxiety or depression.

Our study has some limitations. One of them was the difficulty of contacting students in the clerkship, especially those attending the $11^{\text {th }}$ and $12^{\text {th }}$ semesters of the course, because they are distributed in smaller groups, with activities in different sectors inside and outside the university. As higher means of anxiety and depression were found among students in the $11^{\text {th }}$ semester of University $B$, we questioned whether this finding could have a participation bias, due to the adherence of more anxious or depressed students. Another limitation was the use of self-completed instruments, which are subject to social desirability. Additionally, it was not asked whether the participant used any drugs for depression or anxiety, which could indicate their presence among them and would increase the number of students with depression and anxiety diagnosis. Also, only the biological sex was considered and not gender identity. Finally, a limitation that has occurred in studies on the prevalence of anxiety and depression is the variability of their prevalence resulting from different cutoff points in their classification, even in the same instrument. 
We draw attention to the high prevalence of anxiety, depression and suicidal ideation among medical students in our study. We hypothesize that students who put themselves in the patient's place, starting to feel like them and losing their own perspectives, may have greater anxiety, which can also generate greater stress and loss of therapeutic potential.

We therefore suggest greater attention to students' mental health, seeking strategies to promote it as well to prevent and treat its harm, as it is necessary to take care of these students, so they can feel well throughout the course and can, in the future, take care more efficiently of their health and the health of the population attended by them.

\section{CONCLUSIONS}

The prevalence of anxiety, depression and suicidal ideation among medical students was high, in line with the findings in the literature. The mean scores of empathy, anxiety and depression were higher in women than in men.

Empathy was higher among students who intended to pursue people-oriented specialties and there was no change in their means throughout the course.

Depression and anxiety remained stable throughout the course, except for higher anxiety and depression rates among students in the $11^{\text {th }}$ semester of one of the assessed universities.

There was an association between severe anxiety and the JSE 'Walking in patient's shoes' subscale, which was more related to empathic stress. More studies should be carried out to investigate this association.

The findings demonstrate the urgent need for attention and care to the mental health of medical students, showing that the responsibility of educators and managers related to this issue is high.

\section{ACKNOWLEDGEMENTS}

The authors would like to thank for the financial support of the Scientific Initiation scholarship granted by CNPq-UFSC to the first author, the students who participated in the study and everyone who participated with contributions.

\section{AUTHORS' CONTRIBUTION}

Camila Brunfentrinker participated in the project design, data collection and analysis, and in the drafting and review of the manuscript, which was the scientific initiation research (which received an award as one of the two best studies in the area of Life Sciences) and Term Paper that was presented as a requirement for the undergraduate course in Medicine at UFSC. Regina Pinho Gomig participated in the project design, data collection and analysis, and in the drafting of the manuscript. Suely Grosseman participated as Camila Brunfentrinker's advisor and in the project design, data collection and analysis, drafting and review of the manuscript and preparing the project, data collection and analysis.

\section{CONFLICTS OF INTEREST}

The authors declare no conflicts of interest.

\section{SOURCES OF FUNDING}

The research project was funded by a Scientific Initiation Scholarship granted by CNPq-UFSC 217 - 2018 under the name 'Project Empathy and Depression in Medical Students: a study in two universities in Santa Catarina" (registered in the Integrated System of Research and Extension Project Management Program) and under number 201702963, which granted a scholarship to Camila Brunfentrinker, under the supervision of Suely Grosseman, and was awarded as one of the two best scientific initiation works in the area of Life Sciences.

\section{REFERENCES}

1. Dyrbye LN, Thomas MR, Shanafelt TD. Systematic review of depression, anxiety, and other indicators of psychological distress among U.S. and Canadian medical students. Acad Med. 2006;81(4):354-73.

2. Thomas MR, Dyrbye LN, Huntington JL, Lawson KL, Novotny PJ, Sloan JA, et al. How do distress and well-being relate to medical student empathy? A multicenter study. J Gen Intern Med. 2007;22(2):177-83.

3. Dyson R, Renk K. Freshmen adaptation to university life: Depressive symptoms, stress, and coping. J Clin Psychol. 2006;62(10):1231-44.

4. Ludwig AB, Burton W, Weingarten J, Milan F, Myers DC, Kligler B. Depression and stress amongst undergraduate medical students. BMC Med Educ. 2015;15:141.

5. Bellini LM, Baime M, Shea JA. Variation of mood and empathy during internship. Jama. 2002;287(23):3143-6.

6. Holmes $\mathrm{CL}$, Miller H, Regehr G. (Almost) forgetting to care: an unanticipated source of empathy loss in clerkship. Med Educ. 2017;51(7):732-9.

7. Brazeau CM, Schroeder R, Rovi S, Boyd L. Relationships between medical student burnout, empathy, and professionalism climate. Acad Med. 2010;85(10):S33-S6.

8. Hafferty FW, O' Donnell JF. The hidden curriculum in health professional education2015. 1-324 p.

9. Martimianakis MA, Michalec B, Lam J, Cartmill C, Taylor JS, Hafferty FW. Humanism, the Hidden Curriculum, and Educational Reform: A Scoping Review and Thematic Analysis. Acad Med. 2015;90(11).

10. Association AP. DSM-5: Manual diagnóstico e estatístico de transtornos mentais: Artmed Editora; 2014.

11. Gold JA, Hu X, Huang G, Li WZ, Wu YF, Gao S, et al. Medical student depression and its correlates across three international medical schools. World J Psychiatry. 2019;9(4):65-77.

12. Rotenstein LS, Ramos MA, Torre M, Segal JB, Peluso MJ, Guille C, et al. Prevalence of depression, depressive symptoms, and suicidal ideation among medical students: a systematic review and meta-analysis. Jama. 2016;316(21):2214-36.

13. Pacheco JP, Giacomin HT, Tam WW, Ribeiro TB, Arab C, Bezerra IM, et al. Mental health problems among medical students in Brazil: a systematic review and meta-analysis. Braz J Psychiatry. 2017;39(4):369-78.

14. Mao Y, Zhang N, Liu J, Zhu B, He R, Wang X. A systematic review of depression and anxiety in medical students in China. BMC Med Educ. 2019;19(1):327. 
15. Hope V, Henderson M. Medical student depression, anxiety and distress outside North America: a systematic review. Med educ. 2014;48(10):963-79.

16. Pacheco JPG, Silveira JB, Ferreira RPC, Lo K, Schineider JR, Giacomin HTA, et al. Sex inequality and depression among medical students: A global meta-regression analysis. J Psychiatr Res. 2019;111:36-43.

17. Puthran R, Zhang MW, Tam WW, Ho RC. Prevalence of depression amongst medical students: A meta-analysis. Med Educ. 2016;50(4):456-68.

18. Tian-Ci Quek T, Tam W-S, XTran B, Zhang M, Zhang Z, Su-Hui Ho C, et al. The global prevalence of anxiety among medical students: a meta-analysis. Int J Environ Res Public Health. 2019;16(15):2735.

19. Tam W, Lo K, Pacheco J. Prevalence of depressive symptoms among medical students: overview of systematic reviews. Med Educ. 2019;53(4):345-54.

20. Rogers CR. Empathic: An unappreciated way of being. The counseling psychologist. 1975;5(2):2-10.

21. Rogers CR. The foundations of the person-centered approach. Education. 1979;100(2):98-107.

22. Halpern J. What is clinical empathy? J Gen Intern Med. 2003;18(8):670-4.

23. Morse JM, Anderson G, Bottorff JL, Yonge O, O'Brien B, Solberg SM, et al. Exploring empathy: a conceptual fit for nursing practice? Image: Image J Nurs Sch. 1992;24(4):273-80

24. Hojat M, Gonnella JS, Nasca TJ, Mangione S, Vergare M, Magee M. Physician empathy: definition, components, measurement, and relationship to sex and specialty. Am J Psychiatry. 2002;159(9):1563-9.

25. Schreiter S, Pijnenborg GHM, Aan Het Rot M. Empathy in adults with clinical or subclinical depressive symptoms. J Affect Disord. 2013;150(1):1-16.

26. Hirschfeld R, Montgomery SA, Keller MB, Kasper S, Schatzberg AF, Möller $\mathrm{H}-\mathrm{J}$, et al. Social functioning in depression: a review. J Clin Psychiatry. 2000.

27. Burcusa SL, lacono WG. Risk for recurrence in depression. Clin Psychol Rev. 2007;27(8):959-85

28. Kupferberg A, Bicks L, Hasler G. Social functioning in major depressive disorder. Neurosci Biobehav Rev. 2016;69:313-32.

29. Epstein RM, Hundert EM. Defining and assessing professional competence. Jama. 2002;287(2):226-35

30. Sox H, Blank L, Cohen J. ABIM Foundation. American Board of Internal Medicine; ACP-ASIM Foundation. American College of PhysiciansAmerican Society of Internal Medicine; European Federation of Internal Medicine. Medical professionalism in the new millennium: a physician charter. Annals of internal medicine. 2002;136(3):243-6.

31. Inui T. A flag in the wind: educating for professionalism in medicine. Association of American Medical Colleges: Washington, DC; 2003. 2012.

32. Beach MC, Inui T. Relationship-centered care. J Gen Intern Med. 2006;21(1):3-8.

33. Neumann M, Scheffer C, Tauschel D, Lutz G, Wirtz M, Edelhäuser F. Physician empathy: definition, outcome-relevance and its measurement in patient care and medical education. GMS Z Med Ausbild. 2012;29(1).

34. Novack DH. Therapeutic aspects of the clinical encounter. J Gen Intern Med. 1987;2(5):346-55.
35. Stepien KA, Baernstein A. Educating for empathy. J Gen Intern Med. 2006;21(5):524-30.

36. Rakel DP, Hoeft TJ, Barrett BP, Chewning BA, Craig BM, Niu M. Practitioner empathy and the duration of the common cold. Fam Med. 2009;41(7):494.

37. Hojat M, Louis DZ, Markham FW, Wender R, Rabinowitz C, Gonnella JS Physicians' empathy and clinical outcomes for diabetic patients. Acad Med. 2011;86(3):359-64.

38. Del Canale S, Louis DZ, Maio V, Wang X, Rossi G, Hojat M, et al. The relationship between physician empathy and disease complications: an empirical study of primary care physicians and their diabetic patients in Parma, Italy. Acad Med. 2012;87(9):1243-9.

39. Stewart MA. Effective physician-patient communication and health outcomes: a review. CMAJ. 1995;152(9):1423.

40. Beck RS, Daughtridge R, Sloane PD. Physician-patient communication in the primary care office: a systematic review. J Am Board Fam Pract. 2002;15(1):25-38.

41. Hojat M, Gonnella JS, Nasca TJ, Mangione S, Veloksi JJ, Magee M. The Jefferson Scale of Physician Empathy: further psychometric data and differences by sex and specialty at item level. Acad Med. 2002;77(10):S58-S60.

42. Hojat M, Gonnella JS. Eleven years of data on the Jefferson scale of empathy-medical student version (JSE-S): proxy norm data and tentative cutoff scores. Med Princ Pract. 2015;24(4):344-50.

43. Hojat M. Empathy in health professions education and patient care. 2016.

44. Hojat M, Vergare MJ, Maxwell K, Brainard G, Herrine SK, Isenberg GA, et al. The devil is in the third year: a longitudinal study of erosion of empathy in medical school. Acad Med. 2009;84(9):1182-91.

45. Spatoula V, Panagopoulou E, Montgomery A. Does empathy change during undergraduate medical education?-a meta-analysis. Med Teach. 2019;41(8):895-904.

46. Andersen FA, Johansen A-SB, Søndergaard J, Andersen CM, Hvidt EA Revisiting the trajectory of medical students' empathy, and impact of sex, specialty preferences and nationality: a systematic review. BMC Med Educ. 2020;20(1):1-18.

47. Cunha JA. Manual da versão em português das Escalas Beck. São Paulo: casa do psicólogo. 2001;256.

48. Kendall PC, Hollon SD, Beck AT, Hammen CL, Ingram RE. Issues and recommendations regarding use of the Beck Depression Inventory. Cogn Ther Res. 1987;11(3):289-99.

49. Gorenstein C, Andrade L, Filho AHGV, Tung TC, Artes R. Psychometric properties of the Portuguese version of the Beck Depression Inventory on Brazilian college students. J Clin Psychol. 1999;55(5):553-62.

50. Baldassin S, Silva N, de Toledo Ferraz Alves TC, Castaldelli-Maia JM, Bhugra $D$, Nogueira-Martins MCF, et al. Depression in medical students: Cluster symptoms and management. J Affect Disord. 2013;150(1):110-4.

51. Pallant J. SPSS Survival Manual 4 th edition: A step by step guide to data analysis using SPSS version 18: Maidenhead, Berkshire. Open University Press Retrieved on. 2011;10(05):2012. 